\title{
A Methodological Approach for Researching National Classroom Practices
}

\author{
Meng Yew Tee ${ }^{\mathrm{a}}$ \\ Moses Samuel \\ Norjoharuddeen Bin Mohd Nor \\ University of Malaya \\ Shanthi Nadarajan \\ University Malaysia Sarawak
}

\begin{abstract}
Little continues to be known about what actually happens in classrooms, particularly from a national perspective. Descriptions of classroom practices from a national vantage point can provide a bird's eye view of salient patterns and variations within an education system, especially one as centralised as that of Malaysia. With these descriptions, especially if the primary data consists of video recordings, one can also begin to compare movements in classroom practices across time and space; theorise about the nature of practice within the system as well as inform policy deliberations. This paper examines key methodological decisions of conducting a national study to research classroom educational practice within Malaysia's public school system. The case is made for the use of such studies to gain a bird's eye perspective of classroom practices in a national system as well as to lay the foundations for inter-system comparisons. Potential implications and opportunities of these types of studies are also discussed.
\end{abstract}

Keywords: educational process, classroom practice, pedagogical practice, assessment practice, curriculum implementation practice, national study

\section{Introduction}

The purpose of this paper is to discuss the methodological decisions in conducting a broad-based, national- or state-level study to research classroom practices. While there is a body of research of such nature (e.g. Alexander, 2000; Brückmann et al, 2007; Clarke et al, 2006; 2008; Janik \& Seidel, 2009; Klette, 2009b; Lingard et al, 2001; Luke et al, 2005; Simola, 2005; Stigler et al, 1999), every broad-based study has to address the unique characteristics of the local system and context. It is against the backdrop of this existing body of research that we will describe key methodological decisions that went into shaping a study of classroom practice in Malaysia.

What plays out in classrooms within a national education system can and usually remains a mystery to the many education stakeholders, but this is particularly true with policy-makers and to a certain extent, educational researchers. We know, for example, that one of the single most important formal education determinants is effectiveness of teachers. This consensus has grown over the last three decades as research-based evidence continues to emerge (e.g., Hanushek, 1992; Hanushek, Kain, O'Brien, \& Rivkin, 2005; Hill, Rowan, \& Ball, 2005; Rivkin, Hanushek, \& Kain, 2005; Rockoff, 2004; Rothstein, 2009; Rowan, Correnti, \& Miller, 2002; Sanders \& Rivers, 1996; Singh \& Sarkar, 2015; Wright, Horn, \& Sanders, 1997).

While teacher effectiveness is a critical factor, most countries do not have a finger on the pulse of what actually goes on in their classrooms. In Malaysia for example, most of the research on classroom educational practice investigates practices of individual teachers, classrooms, or schools.

\footnotetext{
Correspondence can be directed to: mytee22@yahoo.com or mytee@um.edu.my
} 
Important as this research is, it does not give us a much needed broad-based understanding of the schooling system as a whole. Broad-based studies serve to describe the predominant practices used in the classroom. With this description, one can also begin to compare movements in classroom practices across time and space; establish watermarks of current practices versus good practices; and, theorise the dynamics and underlying assumptions that drive practice within the system. Ultimately, findings from broad-based national studies can inform policy deliberations.

Broad-based national-level and state-level studies have informed national educational policy reforms in countries such as Finland (Simola, 2005; Sahlberg, 2011), Singapore (Luke, Freebody, Lau \& Gopinathan, 2005; Luke \& Hogan, 2006) as well as Australia (Lingard et al, 2001). Finland's renowned education system, for example, was a late starter in developing their education system amongst the Nordic and European nations. The system found its way through evidence-based studies to drive its educational reform and development plan (Simola, 2005; Salhberg, 2011). As recently as the 1990s, classroom practices were found to be quite traditional. Simola $(2005$, p.462), for example, concluded from a major study (Norris et al., 1996) that classroom practices of schools in Finland involved mainly "frontal teaching of the whole group of students" and little "individualized and student-centred forms of instruction." The study Simola cited provided important evidence of how Finland needed to continue to reform and develop its teacher education and professional development.

In Singapore, educational reform efforts after the Thinking Schools, Learning Nation reforms in the late 1990s, led policy makers to formulate the next wave of reforms focusing on the 'black box' of classroom practices, specifically on pedagogy, curriculum and holistic assessment. This reform effort was preceded by a large scale empirical investigation (Luke, Freebody, Lau and Gopinathan, 2005) involving "a rich description of pedagogy and pedagogical change as the central dynamic of the educational experience" (p.15). The research base for educational reform included cross-sectional and longitudinal studies of pedagogy and student pathways across the educational system, as well as analysis of measures of educational achievement and student produced artifact (i.e., work produced in school and at home), and their impact on student pathways and destinations. The Finland and Singapore experiences serve as significant examples of policy processes that were driven by empirical broad-based research on the national level.

This much needed broad-based research on educational practices is critical but often missing in educational systems in the process of transition. Malaysia, for example, has for the most part dealt with education access issues, but now struggles with a system that has had limited success in helping students cultivate higher-order thinking. What is needed is a broad-based study on educational practices in its classrooms. In making the case for the methodological decisions, this paper adds to the existing literature by foregrounding the conceptual basis for describing classroom practice from a national perspective. In the next section, we describe the conceptual basis for the IMCEP (Inquiry into Malaysian Classroom Educational Practices) research project, an on-going large-scale national project on classroom educational practices.

\section{Theoretical Foregrounding}

When conceptualising the IMCEP research project, we asked an overarching question: Why and how do we study national classroom practices? We broke down this question into two parts. First, why is a bird's eye view description of national classroom practices necessary? Secondly, how can these practices seen from a bird's eye view be described in a meaningful way?

The first question is premised on the argument that there's a need to step back from the specifics of the micro level case studies per se to capture the national manifestations of educational practice. Although micro level studies provide in-depth and rich descriptions, they are by themselves inadequate to describe the broader landscape of practice. However, by analysing these micro cases specifically to form a bird's eye view of practice, we can be better equipped to meaningfully describe and theorise practice at a systems level. 
Systems level studies may include broad-based research at two major levels. One is delineated along the lines of administrative units at a country, state, provincial or district level. The other major level is delineated along clusters of schools with common resemblances such as religious schools, vernacular schools, prep schools, private schools and trust schools. In this study, the focus is on the former, specifically at the country level. Educational policy making-especially in developing countries and nations with a centralised education system-are almost always made at a national level. For example, in Malaysia, policy is driven by a federal ministry with a centralised portfolio. The driving forces of national policy combined with cultural adaptations to the schooling process can form salient and distinct national patterns of practice (Givvin et al, 2005). Thus, a systems level national description can begin to identify these saliences to provide a view of discernible patterns and variations across a centralised system.

This leads us to the second question: how can these practices be described and theorised meaningfully at the systems level or specifically in the context of this study, at a country level? In order to derive a systems level view of patterns of practice, one first has to identify a way of analysing salient and meaningful patterns of practice. We argue that this can be achieved by (1) anchoring the analysis against specific theoretical lenses; and, (2) analyzing broad patterns of practice across specific timeframes and within specific contexts that have a common resemblance. The anchoring of the analysis against specific theoretical lenses-across specific timeframes and within particular contexts - provides a framework for meaningful interpretation while serving as a vehicle for achieving analytical objectives (Klette, 2009a). In this study, we adopted a constructivist lens which was in line with the aspirational goals in Malaysia's public education system (Ministry of Education Malaysia Malaysia, 2012). This lens was then used as the basis for selecting the coding frameworks for this study. This will be discussed with greater detail in the methods section.

Recognition of systems level patterns can be used by policy makers and other stakeholders to make better decisions that impact the whole system. For example, the design and implementation of teacher education as well as professional development programmes can be made based on specific data of practice patterns that are prevalent within the system. So, if it can be established, for instance, that across the system teachers are struggling to ask questions that can drive higher order thinking, then the design of teacher education and professional development programmes need to specifically address this issue.

\section{Systems Level Research of Educational Practices: Learnings from the Research Literature}

The purpose of this section is to review the existing literature on systems level studies, and to position this study against that backdrop. The emphasis is on key learnings from the literature to design the Malaysian study.

Givvin et al (2005) argue that national patterns of practice do exist, especially in more centralised systems such as that of Japan. They argued that there are elements within a school system - including the policy, curriculum, physical environment and social dynamics of classrooms-that shape teaching practice. This argument resonates particularly well with Malaysia's centralised public school system where teacher training, curriculum planning, national examinations, key performance indicators (for students and teachers), to school administrative structure, among others, are largely decided at a central or national level. These structural elements alone can significantly shape and give rise to distinctive national patterns of practice. In addition, Givvin et al (2005) also argue that countries have shaped distinctive teaching practices by adapting to national cultural beliefs, expectations, and values, including assumptions about the nature of a subject and how students learn, expectations about the level of students' performance, and the values held for school processes and outcomes.

Over the last two decades, there have been numerous systems level investigations of educational practices. Table 1 below provides a summary listing of system level studies of classroom teaching practices. 
Table 1. System studies of classroom teaching practice (partially adapted from Janik \& Seidel, 2009)

\begin{tabular}{|c|c|c|c|c|c|}
\hline Study & $\begin{array}{l}\text { Objective of } \\
\text { study }\end{array}$ & $\begin{array}{l}\text { System } \\
\text { (country, } \\
\text { state) }\end{array}$ & Sample size & Types of data & Focus of analysis \\
\hline $\begin{array}{l}\text { CPV Video } \\
\text { Study } \\
\text { (Janik, Seidel } \\
\text { \& Najvar, } \\
\text { 2009) }\end{array}$ & $\begin{array}{l}\text { To document } \\
\text { and describe } \\
\text { everyday } \\
\text { teaching, } \\
\text { curricular } \\
\text { comparisons in } \\
\text { teaching and } \\
\text { learning }\end{array}$ & $\begin{array}{l}\text { Czech } \\
\text { Republic }\end{array}$ & $\begin{array}{l}\text { Voluntary } \\
\text { sampling; } 249 \\
\text { lessons in Physics, } \\
\text { Geography, } \\
\text { English, Physical } \\
\text { Education }\end{array}$ & Video recordings & $\begin{array}{l}\text { Opportunities to learn, } \\
\text { modes of classroom } \\
\text { organisation, phases } \\
\text { of the lesson, didactic } \\
\text { tools and media } \\
\text { opportunities to talk }\end{array}$ \\
\hline $\begin{array}{l}\text { Culture and } \\
\text { Pedagogy } \\
\text { (Alexander, } \\
\text { 2000) }\end{array}$ & $\begin{array}{l}\text { To compare } \\
\text { primary } \\
\text { education } \\
\text { policies and } \\
\text { classroom } \\
\text { practices } \\
\text { in England, } \\
\text { France, India, } \\
\text { Russia and } \\
\text { the United } \\
\text { States }\end{array}$ & $\begin{array}{l}\text { England, } \\
\text { France, } \\
\text { Russia, } \\
\text { USA, and } \\
\text { India }\end{array}$ & $\begin{array}{l}30 \text { schools from } \\
5 \text { countries; } 36 \\
\text { lessons analysed }\end{array}$ & $\begin{array}{l}\text { Video } \\
\text { recordings, } \\
\text { photographs, } \\
\text { lesson } \\
\text { transcripts, pre- } \\
\text { and post-lesson } \\
\text { interviews } \\
\text { with teachers, } \\
\text { lesson artifact } \\
\text { (teachers' } \\
\text { lesson plans, } \\
\text { lesson texts/ } \\
\text { worksheets, } \\
\text { students' } \\
\text { written work) }\end{array}$ & $\begin{array}{l}\text { Basic disposition } \\
\text { of the framing and } \\
\text { regulatory elements } \\
\text { of curriculum, space, } \\
\text { pupil organisation, } \\
\text { time and routine/ } \\
\text { rule/ritual, and works } \\
\text { through each of the } \\
\text { others before finishing } \\
\text { with a sustained } \\
\text { analysis of patterns of } \\
\text { classroom interaction } \\
\text { and the dynamics and } \\
\text { content of teacher- } \\
\text { pupil discourse }\end{array}$ \\
\hline $\begin{array}{l}\text { DESI } \\
\text { (Klieme et al., } \\
2006 \text { in Janík } \\
\text { \& Seidel, } \\
2009 \text { ) }\end{array}$ & $\begin{array}{l}\text { To describe } \\
\text { everyday } \\
\text { lessons, to } \\
\text { analyse verbal } \\
\text { communication } \\
\text { within } \\
\text { classrooms }\end{array}$ & Germany & $\begin{array}{l}105 \text { classes in } \\
\text { English as a second } \\
\text { language }\end{array}$ & Video recordings & $\begin{array}{l}\text { Aspects of } \\
\text { instructional quality, } \\
\text { dealing with mistakes, } \\
\text { efficiency of classroom } \\
\text { management, } \\
\text { mediating cultural } \\
\text { studies topics }\end{array}$ \\
\hline $\begin{array}{l}\text { IPN Video } \\
\text { study } \\
\text { (Seidel \& } \\
\text { Prenzel, } \\
\text { 2006; } \\
\text { Bruckmann } \\
\text { et al, 2007) }\end{array}$ & $\begin{array}{l}\text { To describe } \\
\text { patterns of } \\
\text { teaching } \\
\text { and learning } \\
\text { in physics } \\
\text { instruction } \\
\text { to investigate } \\
\text { effects of } \\
\text { teaching on } \\
\text { students' } \\
\text { learning } \\
\text { processes and } \\
\text { outcomes }\end{array}$ & $\begin{array}{l}\text { Germany } \\
\text { and } \\
\text { Switzerland }\end{array}$ & $\begin{array}{l}50 \text { and } 32 \text { teachers } \\
\text { from randomly } \\
\text { selected German } \\
\text { and Swiss schools } \\
\text { respectively; } \\
\text { video recorded } 2 \\
\text { physics lessons per } \\
\text { teacher }\end{array}$ & $\begin{array}{l}\text { Video } \\
\text { recordings, } \\
\text { interviews and } \\
\text { questionnaires }\end{array}$ & $\begin{array}{l}\text { Organisation of } \\
\text { classroom activities, } \\
\text { goal clarity and } \\
\text { coherence, learning- } \\
\text { orientation, dealing } \\
\text { with mistakes and } \\
\text { conceptual change, } \\
\text { scientific inquiry and } \\
\text { the role of experiment }\end{array}$ \\
\hline IMCEP & $\begin{array}{l}\text { To describe } \\
\text { classroom } \\
\text { educational } \\
\text { practices at a } \\
\text { national level }\end{array}$ & Malaysia & $\begin{array}{l}\text { Random sampling } \\
\text { of public } \\
\text { secondary schools } \\
\text { in Malaysia. } \\
410 \text { Science, } \\
\text { Mathematics, } \\
\text { English and Malay } \\
\text { lessons (from } 141 \\
\text { teachers) were } \\
\text { video recorded }\end{array}$ & $\begin{array}{l}\text { Primarily video } \\
\text { recordings. } \\
\text { Surveys were } \\
\text { also collected. }\end{array}$ & $\begin{array}{l}\text { Instructional practices, } \\
\text { in-class assessment } \\
\text { for learning practices, } \\
\text { and curriculum } \\
\text { implementation } \\
\text { practices. }\end{array}$ \\
\hline
\end{tabular}


Continues (Table 1).

\begin{tabular}{|c|c|c|c|c|c|}
\hline Study & $\begin{array}{l}\text { Objective of } \\
\text { study }\end{array}$ & $\begin{array}{l}\text { System } \\
\text { (country, } \\
\text { state) }\end{array}$ & Sample size & Types of data & Focus of analysis \\
\hline $\begin{array}{l}\text { LPS } \\
\text { (Clarke, Keitel } \\
\text { \& Shimizu, } \\
\text { 2006) }\end{array}$ & $\begin{array}{l}\text { To analyse } \\
\text { teaching and } \\
\text { learning }\end{array}$ & $\begin{array}{l}\text { Australia, } \\
\text { China, Czech } \\
\text { Republic, } \\
\text { Philippines, } \\
\text { Hong Kong, } \\
\text { Israel, Japan, } \\
\text { South Africa, } \\
\text { South Korea, } \\
\text { Germany, } \\
\text { Singapore, } \\
\text { Sweden }\end{array}$ & $\begin{array}{l}\text { Purposive } \\
\text { sampling of "good } \\
\text { teachers." At least } \\
30 \text { lessons in every } \\
\text { country; i.e. more } \\
\text { than } 390 \text { lessons in } \\
\text { Mathematics. }\end{array}$ & $\begin{array}{l}\text { Video recordings } \\
\text { of classroom } \\
\text { proceedings } \\
\text { and interviews, } \\
\text { questionnaires, } \\
\text { students' } \\
\text { written work, } \\
\text { test scores }\end{array}$ & $\begin{array}{l}\text { Verbal interaction, } \\
\text { Mathematical } \\
\text { norms, repetition, } \\
\text { role of seatwork, } \\
\text { motivational } \\
\text { strategies, learning } \\
\text { tasks }\end{array}$ \\
\hline
\end{tabular}

\begin{tabular}{|c|c|c|c|c|c|}
\hline $\begin{array}{l}\text { MET } \\
\text { (Cantrell and } \\
\text { Kane, 2013) }\end{array}$ & $\begin{array}{l}\text { To demystify } \\
\text { effective } \\
\text { teaching } \\
\text { practices in the } \\
\text { classroom and } \\
\text { in turn provide } \\
\text { insights into } \\
\text { teacher } \\
\text { evaluation and } \\
\text { professional } \\
\text { development }\end{array}$ & USA & $\begin{array}{l}\text { Randomisation } \\
\text { block sampling: } \\
\text { 2,700 teachers, } \\
\text { over } 100,000 \\
\text { students, grade } \\
\text { 4-9, } 2 \text { school } \\
\text { years (2009-2010 } \\
\& 2010-2011) \text {, } \\
23,000 \text { hours } \\
\text { videotaped } \\
\text { Science, English } \\
\text { and Maths lessons }\end{array}$ & $\begin{array}{l}\text { Observation, } \\
\text { audio and video } \\
\text { recordings, } \\
\text { survey, } \\
\text { assessments }\end{array}$ & $\begin{array}{l}\text { Across a wide } \\
\text { spectrum of } \\
\text { observable data }\end{array}$ \\
\hline $\begin{array}{l}\text { Norway PISA+ } \\
\text { (Ødegaard, } \\
\text { 2006; Klette, } \\
\text { 2009a) }\end{array}$ & $\begin{array}{l}\text { To analyze } \\
\text { the processes } \\
\text { of teaching } \\
\text { and learning } \\
\text { in lower } \\
\text { secondary } \\
\text { Maths, Science } \\
\text { and Reading } \\
\text { classrooms in } \\
\text { Norway }\end{array}$ & Norway & $\begin{array}{l}\text { Purposive } \\
\text { sampling for } \\
\text { maximum } \\
\text { variation: } \\
152 \text { lessons. } \\
\text { Level Grade } 9 \\
\text { Mathematics, } \\
\text { Science \& } \\
\text { Language Arts } \\
\text { classes. } 6 \text { classes } \\
\text { at } 6 \text { different } \\
\text { schools. Each class } \\
\text { observed for } 3 \\
\text { weeks }\end{array}$ & $\begin{array}{l}\text { Video recording, } \\
\text { student } \\
\text { and teacher } \\
\text { interviews, } \\
\text { students' work }\end{array}$ & $\begin{array}{l}\text { Analysis primarily } \\
\text { focussed on } \\
\text { the teacher, } \\
\text { namely: whole } \\
\text { class instruction; } \\
\text { teachers' activities } \\
\text { during individual } \\
\text { seatwork; teachers' } \\
\text { activities during } \\
\text { group work }\end{array}$ \\
\hline $\begin{array}{l}\text { Pythagoras } \\
\text { (Hugener } \\
\text { et al.,2009; } \\
\text { Janík \& } \\
\text { Seidel,2009) }\end{array}$ & $\begin{array}{l}\text { To investigate } \\
\text { the impact of } \\
\text { mathematics } \\
\text { instruction } \\
\text { on students' } \\
\text { cognitive and } \\
\text { motivational } \\
\text { outcomes }\end{array}$ & $\begin{array}{l}\text { Germany and } \\
\text { Switzerland }\end{array}$ & $\begin{array}{l}\text { Voluntary } \\
\text { sampling; } 19 \\
\text { Swiss and } 20 \\
\text { German classes in } \\
\text { Mathematics }\end{array}$ & $\begin{array}{l}\text { Video } \\
\text { recordings, } \\
\text { questionnaires, } \\
\text { test scores }\end{array}$ & $\begin{array}{l}\text { Teaching patterns, } \\
\text { student-perceived } \\
\text { learning quality, } \\
\text { cognitive activation, } \\
\text { mathematical } \\
\text { achievement }\end{array}$ \\
\hline
\end{tabular}


Continues (Table 1).

\begin{tabular}{|c|c|c|c|c|c|}
\hline Study & $\begin{array}{l}\text { Objective of } \\
\text { study }\end{array}$ & $\begin{array}{l}\text { System } \\
\text { (country, } \\
\text { state) }\end{array}$ & Sample size & Types of data & Focus of analysis \\
\hline $\begin{array}{l}\text { Queensland } \\
\text { School } \\
\text { Reform } \\
\text { Longitudinal } \\
\text { Study } \\
\text { (Lingard et al, } \\
\text { 2001) }\end{array}$ & $\begin{array}{l}\text { To study the } \\
\text { impact of } \\
\text { school-based } \\
\text { management } \\
\text { on student } \\
\text { outcomes }\end{array}$ & $\begin{array}{l}\text { Queensland, } \\
\text { Australia }\end{array}$ & $\begin{array}{l}\text { Purposive } \\
\text { sampling: } 24 \\
\text { schools, } 975 \\
\text { lessons mapped } \\
\text { - Maths, Science, } \\
\text { English, Social } \\
\text { Studies, } \\
\text { Across years 6, 8, } \\
11 \text { plus observed } \\
\text { "outstanding } \\
\text { teachers" }\end{array}$ & $\begin{array}{l}\text { Teacher } \\
\text { questionnaires, } \\
\text { student work, } \\
\text { lessons coded } \\
\text { based on } 20 \\
\text { elements (of } \\
\text { Productive } \\
\text { Pedagogies) }\end{array}$ & $\begin{array}{l}\text { Looked at elements } \\
\text { of productive } \\
\text { pedagogy } \\
\text { (intellectual quality, } \\
\text { connectedness, } \\
\text { supportive } \\
\text { classroom } \\
\text { environment, } \\
\text { working with and } \\
\text { valuing differences) }\end{array}$ \\
\hline $\begin{array}{l}\text { Singapore } \\
\text { Study } \\
\text { (Luke et al, } \\
\text { 2005; Luke \& } \\
\text { Hogan, 2006) }\end{array}$ & $\begin{array}{l}\text { To measure, } \\
\text { map and } \\
\text { model } \\
\text { classroom } \\
\text { pedagogy } \\
\text { and student } \\
\text { outcomes } \\
\text { in a large, } \\
\text { representative } \\
\text { sample }\end{array}$ & Singapore & $\begin{array}{l}\text { Representative } \\
\text { sampling: } 1000 \\
\text { lessons in } 56 \\
\text { schools in Primary } \\
5 \text { and Secondary } \\
3 \text { (Mathematics, } \\
\text { Science, English, } \\
\text { Tamil, Chinese, } \\
\text { Malay, and Social } \\
\text { Studies) }\end{array}$ & $\begin{array}{l}\text { Observation, } \\
\text { audio and video } \\
\text { recording, } \\
\text { survey, sample } \\
\text { artefacts and } \\
\text { achievement } \\
\text { scores }\end{array}$ & $\begin{array}{l}\text { Multiple areas, } \\
\text { with classroom } \\
\text { data emphasising } \\
\text { content, } \\
\text { pedagogical } \\
\text { and assessment } \\
\text { practices, as well as } \\
\text { lesson structure }\end{array}$ \\
\hline $\begin{array}{l}\text { TIMSS } 1995 \\
\text { (Stigler et al, } \\
\text { 1999) }\end{array}$ & $\begin{array}{l}\text { To provide a } \\
\text { rich account } \\
\text { of } 8^{\text {th }} \text { grade } \\
\text { Maths classes } \\
\text { in three } \\
\text { countries }\end{array}$ & $\begin{array}{l}\text { USA, } \\
\text { Germany, } \\
\text { Japan }\end{array}$ & $\begin{array}{l}\text { Various forms } \\
\text { of probabilistic } \\
\text { sampling: } 231 \\
\text { Maths lessons }\end{array}$ & Video recordings & $\begin{array}{l}\text { Content, } \\
\text { organisation } \\
\text { of lesson and } \\
\text { instructional } \\
\text { practices }\end{array}$ \\
\hline $\begin{array}{l}\text { TIMSS } 1999 \\
\text { (Hiebert et al, } \\
\text { 2003) }\end{array}$ & $\begin{array}{l}\text { To investigate } \\
\text { and describe } \\
\text { teaching } \\
\text { practices in 8th } \\
\text { grade Maths } \\
\text { and Science } \\
\text { classrooms in } \\
\text { seven } \\
\text { countries }\end{array}$ & $\begin{array}{l}\text { Australia, } \\
\text { Czech } \\
\text { Republic, } \\
\text { Hong Kong, } \\
\text { Netherlands, } \\
\text { Switzerland, } \\
\text { USA, Japan }\end{array}$ & $\begin{array}{l}\text { Various forms } \\
\text { of probabilistic } \\
\text { sampling: } 638 \\
\text { Maths lessons } \\
\text { and } 439 \text { Science } \\
\text { lessons }\end{array}$ & Video recordings & $\begin{array}{l}\text { Structure of } \\
\text { lesson, content } \\
\text { and instructional } \\
\text { practices }\end{array}$ \\
\hline
\end{tabular}

One way to investigate teaching practices within a system is to do a large-scale survey (Rowan, Correnti \& Miller, 2002). Examples of large-scale surveys include the Teaching and Learning International Survey (TALIS) (OECD, 2014) and a number of survey studies carried out in several countries using the "What Is Happening In Class? (WIHIC)" questionnaire (Fraser \& Goh, 2003). The TALIS survey was able to provide valuable data on such dimensions as teacher's self-efficacy, beliefs and attitudes towards teaching and learning, as well as their perception of their own teaching practice. The 2013 TALIS survey, for instance, found that Malaysian teachers predominantly see their role as facilitators and leaned towards constructivist beliefs. However, it is not clear from the self-reports if 
their practice is consistent with their beliefs. Likewise, the teachers' practices as facilitators in terms of helping students learn is not apparent. We therefore argue that these practice related issues can only be investigated by in-situ classroom observations.

Large scale video studies have broken new ground in helping us study classroom practice at a system level. One of the earliest and most well-known is the Trends in International Mathematics and Science Study (TIMSS) 1995 study (Stigler et at, 1999). This international comparative research project used various forms of probabilistic sampling to obtain nationally representative samples of teachers in the USA, Germany and Japan. They video recorded one lesson each from 231 eighthgrade mathematics classrooms. In the 1999 study, they recorded 638 mathematic lessons and 439 science lessons from seven different countries (Hiebert et al, 2003). Both these studies focused on lessons structures and instructional practices anchored against learning goals and specific content parameters. The IMCEP study, instead, focused on a combination of dimensions including assessment for learning, curriculum implementation as well as pedagogical practices as they form the core dimensions of classroom practice.

Several other systems studies where then conducted after the TIMSS studies. We specifically focus on the broader purpose of these research initiatives; the way data was collected; and, the way data was analysed.

\section{Purpose and Focus of Systems Level Studies}

Systems level studies have been initiated at different junctures in the education reform process. Singapore and Finland utilised systems level studies as a precursor to reform, using the findings as a basis for identifying key aspects for structural reforms (refer to Table 1). The results of these studies set the stage for both systems to initiate moves towards curriculum and pedagogical structures that emphasised thinking skills as opposed to rote learning.

On the other hand, the Queensland School Reform Longitudinal Study (2001) was more focused on assessing the impact of ongoing reforms at that time. Among other things, this study looked at aspects of productive pedagogies - including depth of understanding, knowledge connectedness, harnessing the richness of diversity and, conducive learning environments-and its impact on student outcomes. The findings from this study helped identify more clearly directions for continuing reform. Similarly, the Norway PISA+ study was used to better define issues arising from the international Programme for International Student Assessment (PISA) study.

With the IMCEP study, there was a distinct need to conduct a systems study in order to identify and describe the watermark of classroom educational practice in Malaysian public schools. Since Malaysia's independence in 1957, there have been numerous education reform efforts. In the midst of these reforms, systems level studies focusing on practice patterns have been scarce. The most recent government-initiated study cited in the Malaysian Education blueprint (Ministry of Education Malaysia, 2012) broadly identifies issues of practice in Malaysian classrooms but does not adequately describe and conceptualise specific aspects of teacher practice for development. A study such as IMCEP is needed to describe with a greater specificity practice patterns that are deemed most pertinent to the system today, such as dealing with the question "at the systemic level, what instructional and assessment for learning opportunities are made available to help students develop thinking skills?"

In the long run, the IMCEP study also provides a platform to do comparisons with other national systems and existing educational practice benchmarks. International comparative studies such as the TIMSS video studies can help national educational systems such as that of Malaysia to benchmark, explore and identify potential educational policy and practices for more deliberate discussions and initiatives. With the durability of video data, these comparisons can be made over time and with other systems that have common features but different success profiles. 


\section{Methodological and Theoretical Framing of Systems Level Studies}

Klette (2009b) warned that the methodological and theoretical framing assumed by educational researchers can blind us to significant changes to practice. Thus the framing of such systems level studies needs to be done deliberately for the context and purpose in which they exist. Klette (2009b) as well as Artigue and Winslow (2010), for example, argue that a study's framing must have space for modes of data collection and analyses that allows for multiple perspectives, or at the very least, the perspective of local needs. The framing must account for the specifics of the context in which the system resides; the aspirations of the education system; the theoretical premises of conceptualising and analysing practice; levels of analysis; and time scales of investigations. How this backdrop plays out methodologically in IMCEP is discussed in the next section.

\section{Methodological Framing of IMCEP: Background and Design}

Malaysia, or Malaya as it was formerly known, achieved independence from Britain in 1957. At this point, schooling was very much limited to the elite. Only 6 percent of the children had secondarylevel education and a mere 1 percent had any post-secondary education (OECD, 2013). However, the decades thereafter, access to schooling increased dramatically. By 2011, the enrolment rates at primary-level, lower secondary-level and upper secondary-level education had reached 94 percent, 87 percent and 78 percent respectively (Ministry of Education Malaysia, 2012). The emphases on the 3 Rs (reading, writing and arithmetic)-helped Malaysian youth reach near-universal literacy (Ministry of Education Malaysia, 2012).

While the country has made significant improvement in increasing access to formal schooling, the quality of the education system has come under greater scrutiny. The prevailing challenge today is improving the quality of education, particularly in terms of helping students develop higher-order thinking capabilities (Ministry of Education Malaysia, 2012). OECD (2013, p. 207) reported that "learning standards have declined over the last decade" in Malaysia. As an indicator of this decline, the same report stated that Malaysia had the largest decline in test scores within the decade among all the countries that participated in TIMSS. Similarly, the PISA study found that Malaysian students struggle with questions that required higher-order thinking (Ministry of Education Malaysia, 2012). In addition, potential employers have expressed serious concerns that significant numbers of Malaysian graduates do not have essential skills related to critical thinking, reasoning, problem-solving, communication, and being able to think and work independently (Ministry of Higher Education Malaysia, 2012).

It is worth noting that these issues are not likely due to a lack of resources. For instance, it was reported in 2008 that Malaysia ranked 16th in terms of government spending on education out of 102 countries surveyed (Ministry of Education Malaysia, 2012).

One of the key areas of concern is what happens in Malaysian public school classrooms. The Malaysian Education Blueprint (Ministry of Education Malaysia, 2012, p. 5-2) reported, based on observations of 125 lessons in 41 schools, that typically lessons in Malaysian classrooms "did not sufficiently engage students, relying on a more passive lecture format of content delivery by the teacher." The same study also concluded that classroom experiences were more focused on "surface-level content understanding for summative assessment purposes, rather than on cultivating higher-order thinking skills."

While this study is useful for providing a broad understanding of what happens in Malaysian classrooms, a more theoretically-grounded and granular analysis of practice is needed. Such an analysis would have to account for major dimensions of classroom practices including instruction, assessment and curriculum implementation. The analyses of these dimensions have to be underpinned by a conceptual foundation that is robust and still keep in focus Malaysia's education needs and aspirations. Malaysia's needs, as discussed earlier, are aimed at increasing the quality of education through practices that are more conducive to the development of higher order thinking. Furthermore, the demands of the knowledge economy, globalisation and the need for a well-informed 
citizenry requires that students have ample opportunities to learn to think critically and creatively as well as collaborate, problem solve and communicate effectively in rapidly changing environments. Existing evidence suggests that constructivist approaches would help the development of such skills (Bransford et al, 1999; Hmelo-Silver, 2004; Swartz, Fischer \& Parks, 1998). For these reasons, IMCEP selected a constructivist lens to underpin the analyses. However, taking into consideration Klette's (2009b) warning of how a pre-selected research lens can possibly blind us as educational researchers, the IMCEP research team decided that it is crucial that the data be collected in video format so that other lenses can be subsequently used to allow other perspectives to enrich the analytical base.

Having established the initial framing, other key research design decisions involving sampling, data collection and data analysis were made.

\section{Sampling Strategy}

The key driver in designing the sampling strategy was the need to obtain a description of national classroom practices. Previous small-scale, situated studies had found little voice among policy makers as well as other stakeholders in the country. A telling instance is the most recent national education development blueprint (Ministry of Education Malaysia, 2012) that rarely cited smaller-scale, situated studies to buttress the case for policy reforms.

In order to capture descriptions of national classroom practices, a random sampling plan was used which would allow us to obtain a representative view of national patterns of practice, and consequently be more likely to contribute to policy deliberations within the country.

The study focused on Year 7 teachers as Year 7 in Malaysian public education system is the transition year from primary to secondary school. While the initial goal was to sample teachers across the country, a lack of comprehensive list of Year 7 teachers made this unachievable. Because of this practical challenge, we opted instead to randomly sample schools rather than individual teachers.

Eventually, the IMCEP sampling plan involved randomly selecting from the list of almost 2000 public secondary schools in Malaysia which accounts for 88 percent of the secondary school student population in Malaysia (Ministry of Education Malaysia, 2012). The Mathematics, Science, English Language and Malay Language teachers in the selected schools were approached for consent to be participants in the study. These four subjects were selected as they constitute the core subjects in the secondary school curriculum. In total, 24 schools and 140 teachers consented to be part of the study. Our goal was to obtain data from at least 30 teachers per school subject to enable various inferential statistical analyses, such as comparing practices between school subjects and correlating observed practices with espoused practices.

\section{Data Collection Strategy}

A major challenge one has to anticipate in system level studies is the complexity of data collection. In the context of IMCEP, two primary data sources were collected, namely, video data and survey data.

Video recordings were used as a form of observation, with a number of added advantages over live observations (Erickson, 2011). Video recordings provide lasting records that makes it possible to pause, re-scrutinize, and re-interpret teaching and learning processes by multiple researchers (Erickson, 2011; Klette, 2009a). Video also provides a visual representation of aspects of classroom processes that may escape the observer's gaze. In addition, Janik, Seidel and Najvar (2009) also point out that video studies allow researchers to code and re-code as required in order to capture the rich complexity of classroom practices. As pointed out earlier, this was a key requirement for this study to allow the possibility of different analyses from multiple perspectives.

The decision was also made to record three lessons per teacher over a period of a week. Praetorius et al (2014) found that one lesson was enough to identify teaching patterns related to classroom management and teacher-student interaction structures, but more lessons were needed to identify stable teaching patterns related to cognitive activation (which includes dimensions such 
as students' ways of thinking and challenging high-cognitive activities). Since the focus of the IMCEP study was on general patterns of practice, recording one lesson per teacher may have been adequate but we wanted to minimize the possibility that the lesson chosen for observation was an outlier. In this regard, other researchers have recorded three lessons per teacher (Seidel and Prenzel, 2006; Hugener et al., 2009). A recording of three lessons per teacher thus allowed us at least three data sets to establish patterns of practice. This was done over the course of a week as the research team spent a work week at the school before moving on to the next site.

For each lesson recorded, two video cameras and one audio recorder was used. The first camera was stationed at the back of the class focusing on the teacher, and the second more compact camera was stationed at the front of the class to capture a whole-class perspective. This arrangement allowed for two observational vantage points. The audio recorder was attached to the teacher to ensure clear audio quality.

In selecting lessons for recording, the teachers were given the option to choose lessons of their choice in the given week. This was done usually a week before the actual recording to ensure the teacher was available for recording, as well as to put teachers at ease. While we requested for teachers to 'do what they usually do,' it is quite likely that this arrangement would lead teachers to put their best foot forward. Still, for the purposes of this study, we argue that their broad patterns of practice would not differ too much from their usual approach to teaching. For example, if the teacher was accustomed to chalk-and-talk, it would be unlikely that the teacher would adopt, for instance, a problem-based learning approach.

The IMCEP project also used a survey to collect demographic and teachers' background data as well as teachers' thoughts on their practice. These data will be analysed separately and also in relation to the classroom video data.

In all situations, consent and permission were obtained from the teachers, the school principal as well as relevant state and national agencies. The teachers were briefed in face-to-face settings, and were given opportunities to ask any questions. They also knew that they reserved the right to withdraw their consent at any time. While withdrawal occurred several times, an open communication stance to address any emerging concerns significantly helped teachers be more at ease with being video recorded.

\section{Data Analysis Strategy}

Malaysia's education planning blueprint (Ministry of Education Malaysia, 2012) explicitly cites the importance of engaging students in types of learning experiences that foreground higher order thinking. Teachers in Malaysian public schools are already familiar with thinking and approaches often associated with constructivism (OECD, 2014). For instance, most teachers see themselves as facilitators. However, as discussed earlier, it is still unclear whether teachers' practice in the classroom reflects constructivist pedagogies often associated with the development of higher order thinking.

For these reasons, the initial analysis is underpinned by a constructivist lens keeping open the possibility of using other theoretical lenses in subsequent analyses. This underpinning helped frame the study in terms of three major, inter-connected classroom practice areas, namely instructional practice, assessment practice and curriculum implementation practices.

If the richness and complexity of practice is to be described for the purposes of a bird's eye view, salient units of analyses, scale and foci will have to be identified to make sense of the data. Klette (2009b) argues that the use of a priori coding frameworks helps with reducing complexity in large-scale video studies. In addition, using an a priori coding framework as a template for analysis enables us to explore resemblances of practice against established good practices. The notion of resemblance builds on the idea that similar categories exhibit a gradient structure wherein some practices are better exemplars of good practices than others (Rosch, 1978; Sternberg \& Horvath, 
1995; Smith \& Strahan, 2004). In other words, the greater the similarity of exhibited practice with the coding framework, the greater the probability that it belongs to the category. This posits the need for using coding frameworks in instructional, assessment and curriculum implementation practices that provide a basis for comparisons against existing good practices. Thus, these practical as well as conceptual considerations support and add to the existing literature on how to make sense of video data to gain a national perspective on classroom practices.

After a review of existing coding frameworks for studying classroom educational practices (e.g. Lingard, Hayes, \& Mills, 2003; Luke, Freebody, Cazden, \& Lin, 2004; Tedlie et al, 2006; Danielson, 2007, 2011, 2013; Pianta, La Paro, \& Hamre, 2008; Hill et al., 2008; Klette, 2009b; Grossman et al., 2010; Kane \& Staiger, 2012; Kane et al., 2013), the decision was made to adopt Framework For Teaching or FFT (Danielson, 2011). It was then adapted to analyse instructional practice because of its constructivist underpinnings which is consistent with the project and national goals, as well as its established track record. The FFT has been widely used in different research projects and have been found to be robust (Kane \& Staiger, 2012).

As for analysing assessment practices, the IMCEP research team had to develop its own coding framework based on the Assessment for Learning conceptions (Black et al, 2004; Black et al, 2006). A key reason for this decision was that Malaysia had just began implementing school-based assessment (from 2012) on a nationwide scale which emphasised assessment for learning. This was a strategic time to study classroom assessment practices three years into the implementation of this school-based assessment policy.

The coding framework for analysing curriculum implementation was adapted from two sources, namely Brown's (2009) and Lingard, Hayes and Mills' (2003) characterisation of how teachers use curriculum. Brown's work provided the foundation to answer a key question in relation to how teachers in Malaysia implemented the national curriculum i.e. did they offload, adapt or improvise the curriculum as they carried out the lessons? Lingard et al.'s productive pedagogies framework, on the other hand, provided the lens for the project to study if teachers in Malaysia connected the formal curriculum to other disciplines as well as students' real world experiences. Both frameworks were essential in helping us understand how teachers were adjusting their practices in the midst of a centralised national curriculum.

Fundamentally, the coding frameworks were decided based on what was deemed essential to Malaysia's current context, including its aspirations and on-going challenges. The national aspiration to help students develop higher level thinking abilities keyed the constructivist underpinning for all our initial coding framework. This underpinning formed a cohesive lens for studying Malaysian teachers' classroom pedagogical practices, including their instructional, assessment and curriculum implementation practices.

It is important to note that the methodological details we have outlined here can be used by other independent research projects to not only gain a birds'-eye view of their respective education system, but also lay the foundations for comparing with the Malaysian data - as long as the sampling, video recording and coding scheme are similar. In other words, it is possible for similar studies to be done in different systems quite autonomously, and eventually for the data to be compared to reveal a more nuanced understanding of each system.

\section{Initial Findings}

This section is to provide some initial data as an example of findings that can emerge from such a study. The aim is not to provide a full report of the findings but to illuminate the kinds of findings that this study yields. 
Figure 1. Example of findings from the IMCEP study

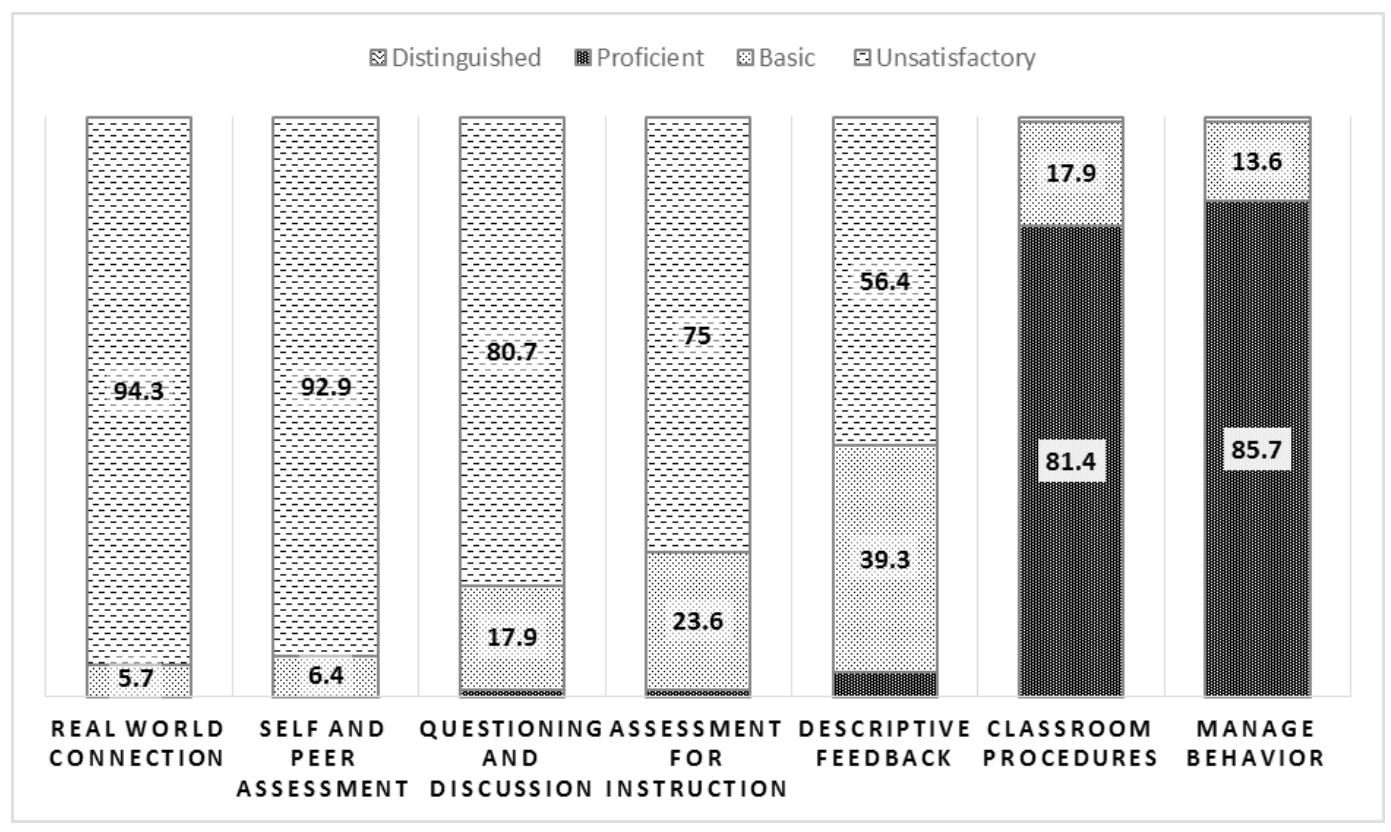

The IMCEP study found that most Malaysian teachers were quite proficient in managing classroom procedures as well as student behavior. The teachers established procedures and routines for classroom management that limited time wastage as well as to disruptions from negative student behavior.

However, a majority of Malaysian teachers struggled with: making real world connections, conducting self- and peer-assessments, asking high-quality questions and facilitating discussions, assessing for instruction as well as providing descriptive feedback. In all these categories, a majority of 140 teachers video-recorded were coded as having "unsatisfactory" practices.

Most of the teachers did not make any real-world connections (94, 3 percent) during lessons, and thus was coded as "unsatisfactory." The remaining 5.7 percent was coded as "basic" i.e. attempts were made to make real-world connections. None were "proficient" or "distinguished" in successfully connecting students' own experiences and contemporary external situations to the topic being studied in class.

The findings from the next four practice areas were particularly surprising during a time when formative and a more holistic assessment system were being emphasised. The school-basedassessment policy began its secondary school implementation phase in 2012, beginning with Year 7 . By the time the IMCEP data was being collected in Year 7 classrooms, the policy was already in the third year of implementation. It was to be more holistic and more focused on assessing the "learning process" rather than just the learning output (Ministry of Education Malaysia, 2011).

A majority of the teachers' practice in areas very much related to the school-based assessment policy were coded as "unsatisfactory." Nearly 93 percent did not create any opportunities for students to assess their own or each other's work. More than 80 percent asked questions that were of low cognitive challenge, and spoke to students predominantly in recitation style rather than facilitating discussions. Most of the teachers (75 percent) also showed little or virtually no assessment or monitoring of student learning. And more than 56 percent demonstrated little evidence of giving feedback, and when they did it was of substandard quality. 
These initial findings provide some explanation for the slide in Malaysia's education achievement scores based on international assessments. In the last decade, for example, Malaysia witnessed the largest decline in test scores of all countries participating in TIMSS (UNESCO, 2014, p.221). International assessments such as TIMSS are designed increasingly to measure higher order thinking capacities such as problem-solving. In this regard, IMCEP has found that Malaysia's classrooms provide very limited opportunities for students to practice and develop their higher thinking order capacities. The overwhelming uniformity of the findings across the system suggests that it is a systemic issue at the national level. While international comparisons such as TIMSS and PISA show us where a country stands in relation to others, national-level studies provide a birds-eye view that can pinpoint systemic issues that are country specific.

In this example, it is clear that teachers need support and development opportunities to enhance their classroom practice. While the teachers are qualified with teacher education degrees, it cannot be assumed that they will necessarily transition into these practice areas with ease. Thus, a policy formulation for such reform must take into account the bridging process between preservice and in-service teacher education, through which teachers can progressively develop the necessary knowledge and competencies.

Perhaps as importantly, these data also reveal that teachers' practice may be rooted in a different epistemic position than what the education system aspires. The teachers' practice suggest that they are still entrenched in a more didactic, teacher-centered stance. Constructivist practices that strive for co-construction of knowledge requires a paradigm shift. In this regard, training alone may not suffice. Transforming mental models will require a cultural shift enabled by a more comprehensive, sustained change process.

\section{Conclusion}

The purpose of this paper was to discuss the design of a study focused on describing a birds' eye view of classroom educational practices in Malaysia. This perspective can be particularly meaningful in describing common and distinctive practices enacted within a centralised system, and consequently provide empirical data for contributing to policy discussions in one of the most important areas in education - what happens in the classroom in relation to national aspirations, policies and practices.

In explicitly articulating the methodological design of IMCEP, we hope to stimulate further dialogue and initiatives for comparative analyses of systems around the world. These comparative analyses can take several forms: it can involve one umbrella study involving multiple countries (such as the TIMMS video study), or it can involve independent national studies done by different research groups in different countries. With the latter option, these independent studies can be analysed together if enough methodological congruence is present. Such methodological congruence can arise from following these three key methodological moves implemented in this study: first, random sampling to allow for analysis of representative patterns of practice; second, a data collection approach that uses a 2-video camera and 1-audio recorder format; and, thirdly, the use of a similar coding framework. These similarities will allow for independent projects to be tied together for comparative analyses.

Apart from inter-national comparisons, the above framework can also be used to compare practices within a system over a period of time (e.g. every 5 years) or at critical junctures of an education system (e.g. before and after a major reform effort). At the very least, this birds' eye view perspective can provide a valuable snapshot of practice within a system.

\section{Notes}

This work was funded in part by the University of Malaya Research Grant (UMRG) RP004-13SBS, the Equitable Society Research Cluster and the University of Malaya Rakan Penyelidikan Grant CG035-2013. Thanks also to our colleagues Esther Daniel, Renuka Sathasivam, Ting Su Hie as well as numerous graduate students who participated in the discussions for designing this study. 


\section{References}

Alexander, R. (2000). Culture and Pedagogy: International comparisons in primary education. Oxford: Blackwell.

Artigue, M., and Winsløw, C. (2010). International comparative studies on mathematics education: A viewpoint from the anthropological theory of didactics. Recherches en didactique des mathématiques, 30(1), pp. 47-82.

Black, P., Harrison, C., Lee, C., Marshall, B. and Wiliam, D. (2004). Working inside the black box: Assessment for learning in the classroom. Phi Delta Kappan, September 2004, pp. 9-21.

Black, P., McCormick, R., James, M. and Pedder, D. (2006). Learning how to learn and assessment for learning: A theoretical inquiry. Research Papers in Education, 21(2), pp. 119-132.

Bransford, J. D., Brown, A. L., and Cocking, R. R. (1999). How People Learn: Brain, mind, experience, and school. Washington DC: National Academy Press.

Brown, M. (2009). The teacher-tool relationship: Theorizing the design and use of curriculum materials. In J. Remillard, G. Lloyd and B. Herbel-Eisenmann (Eds.), Mathematics Teachers at Work: Connecting curriculum materials and classroom instruction. London: Routledge, pp.17-36.

Brückmann, M., Duit, R., Tesch, M., Fischer, H., Kauertz, A., Reyer, T., Gerber, B., Knierim, B. and Labudde, P. (2007). The potential of video studies in research on teaching and learning science. In Pintó, R., \& Couso, D. (Eds.), Contributions from Science Education Research. Dordrecht: Springer, pp. 77-89.

Cantrell, S., and Kane, T. J. (2013). Ensuring Fair and Reliable Measures of Effective Teaching: Culminating findings from the MET project's three-year study. MET Project Research Paper. Available at: http://www. metproject. org/ downloads/ MET Ensuring Fair and Reliable Measures Practitioner Brief.pdf [Accessed 1 February 2016].

Clarke, D., Keitel, C., and Shimizu, Y. (Eds.). (2006). Mathematics Classrooms in Twelve Countries: The insider's perspective (Vol. 1). Rotterdam/Taipei: Sense Publishers.

Danielson, C. (2007). Enhancing Professional Practice: A framework for teaching. Alexandria, VA: Association for Supervision and Curriculum Development.

Danielson, C. (2011). The Framework for Teaching Evaluation Instrument (2011 edition). Princeton, $\mathrm{NJ}$ : The Danielson Group.

Danielson, C. (2013). The Framework for Teaching Evaluation Instrument (2013 edition). Princeton, NJ: The Danielson Group.

Erickson, F. (2011). Uses of video in social research: a brief history. International Journal of Social Research Methodology, 14(3), pp. 179-189.

Fraser, B. J., and Goh, S. C. (2003). Classroom learning environments. In In J.P. Keeves, R. Watanabe, R. Maclean, P.D. Renshaw, C. Power, R. Baker, S. Gopinathan, W. Ho, C.C. Yin, A.C. Tuijnman (Eds.), International Handbook of Educational Research in the Asia-Pacific Region. Dordrecht: Springer, pp. 463- 475.

Givvin, K. B., Hiebert, J., Jacobs, J. K., Hollingsworth, H., and Gallimore, R. (2005). Are there national patterns of teaching? Evidence from the TIMSS 1999 video study. Comparative Education Review, 49(3), pp. 311-343.

Grossman, P., Loeb, S., Cohen, J., Hammerness, K., Wyckoff, J., Boyd, D., et al. (2010). Measure for Measure: The relationship between measures of instructional practice in middle school English language arts and teachers' value-added scores. Washington, DC: CALDER.

Hanushek, E.A. (1992). The trade-off between child quantity and quality. Journal of Political Economy, 100(1), pp. 84-117.

Hanushek, E. A., Kain, J. F., O’Brien, D. M., and Rivkin, S. G. (2005). The Market for Teacher Quality. (Working Paper No. 11154). Cambridge, MA: National Bureau of Economic Research.

Hiebert, J., Gallimore, R., Garnier, H., Givvin, K.B., Hollingsworth, H., Jacobs, J., Chui, A. M., Wearne, D., Smith, M., Kersting, N., Manaster, A., Tseng, E., Etterbeek, W., Manaster, C., Gonzales, P., and Stigler, J. (2003). Teaching Mathematics in Seven Countries: Results from the TIMSS 1999 
Video Study. NCES (2003-013). U.S. Department of Education. Washington DC: National Centre for Education Statistics.

Hill, H.C., Blunk, M., Charalambous, C., Lewis, J., Phelps, G.C., Sleep, L., et al (2008). Mathematical knowledge for teaching and the mathematical quality of instruction: An exploratory study. Cognition and Instruction, 26(4), pp. 430-511.

Hill, H.C., Rowan, B., and Ball, D.L. (2005). Effects of teachers' mathematical knowledge for teaching on student achievement. American Educational Research Journal, 42(2), pp. 371-406.

Hmelo-Silver, C. E. (2004). Problem-based learning: What and how do students learn? Educational Psychology Review, 16(3), pp. 235-266.

Hugener, I., Pauli, C., Reusser, K., Lipowsky, F., Rakoczy, K., and Klieme, E. (2009). Teaching patterns and learning quality in Swiss and German mathematics lessons. Learning and Instruction, 19(1), pp. 66-78.

Janik, T., and Seidel, T. (Eds.). (2009). The Power of Video Studies in Investigating Teaching and Learning in the Classroom. Münster: Waxmann Publishing.

Janik, T., Seidel, T., and Najvar, P. (2009). Introduction: On the power of video studies in investigating teaching and learning. In T. Janik and T. Seidel (Eds.), The Power of Video Studies in Investigating Teaching and Learning in the Classroom. Münster: Waxmann Publishing, pp. 7-19.

Kane, T. J., McCaffrey, D. F., Miller, T., and Staiger, D. O. (2013). Have We Identified Effective Teachers? Validating Measures of Effective Teaching Using Random Assignment. Research Paper. MET Project. Bill \& Melinda Gates Foundation.

Kane, T. J., and Staiger, D. O. (2012). Gathering Feedback for Teaching: Combining High-Quality Observations with Student Surveys and Achievement Gains. Research Paper. MET Project. Bill \& Melinda Gates Foundation.

Klette, K. (2009a). Blindness to change within processes of spectacular change? What do educational researchers learn from classroom studies?. In A. Hargreaves, A. Lieberman, M. Fullan and D. Hopkins (Eds.), Second International Handbook of Educational Change (pp. 1001-1015). Dordrecht: Springer, pp. 1001-1015.

Klette, K. (2009b). Challenges in Strategies for Complexity Reduction in Video Studies. Experiences from the PISA+Study: A video study of teaching and learning in Norway. In T. Janik, and T. Seidel (Eds.), The Power of Video Studies when Investigating Teaching and Learning in Classrooms. Münster: Waxmann Publishing, pp.61-82.

Lingard, B., Hayes, D., and Mills, M. (2003). Teachers and productive pedagogies: Contextualising, conceptualising, utilising. Pedagogy, Culture and Society, 11(3), pp. 397-422

Lingard, R. L., Ladwig, J., Mills, M. D., Hayes, D., Luke, A., Gore, J., and Christie, P. H. (2001). The Queensland School Reform Longitudinal Study: A Strategy for Shared Curriculum Leadership. Teachers' Manual. Brisbane: State of Queensland (Department of Education).

Luke, A., Freebody, P., Cazden, C., and Lin, A. (2004). Singapore Pedagogy Coding Scheme. Singapore: Centre for Research in Pedagogy and Practice.

Luke, A., Freebody, P., Lau, S. and Gopinathan, S. (2005). Towards research-based innovation and reform: Singapore schooling in transition. Asia Pacific Journal of Education, 25 (1), pp. 5-28.

Luke, A., and Hogan, D. (2006). Redesigning what counts as evidence in educational policy: The Singapore model. In J. Ozga, T. Popkewitz, and T. Seddon (Eds.), World Handbook of Education. Dordrecht, Netherlands: Kluwer, pp. 170-184.

Ministry of Education Malaysia (2011). Frequently Asked Questions: PBS concept. Ministry of Education Malaysia, Government of Malaysia. Available at: http://www.moe.gov.my/en/soalan-lazimview?id=147\&keyword=\& [Accessed 1 February 2016].

Ministry of Education Malaysia (2012). Malaysia Education Blueprint 2013-2025. Putrajaya: Ministry of Education Malaysia, Government of Malaysia.

Ministry of Higher Education Malaysia (2012). The National Graduate Employability Blueprint 20122017. Putrajaya: Ministry of Higher Education, Government of Malaysia. 
Norris, N., Asplund, R., MacDonald, B., Schostak, J. and Zamorski, B. (1996). An Independent Evaluation of Comprehensive Curriculum Reform in Finland. Helsinki: National Board of Education.

$\varnothing$ degaard, M. (2006). PISA+: A research project to pursue problematic PISA findings in the Norwegian context. NorDiNa: Nordic Studies in Science Education, 2(2), pp. 5-88.

OECD (2013). Structural policy country notes: Malaysia. In Economic Outlook for Southeast Asia, China and India 2014: Beyond the Middle-Income Trap. Paris: OECD Publishing.

OECD (2014). TALIS 2013 Results: An International Perspective on Teaching and Learning, TALIS. Paris: OECD Publishing.

Pianta, R.C., La Paro, K.M., and Hamre, B.K. (2008). Classroom Assessment Scoring System. Baltimore, Maryland: Paul H. Brookes.

Praetorius, A. K., Pauli, C., Reusser, K., Rakoczy, K., and Klieme, E. (2014). One lesson is all you need? Stability of instructional quality across lessons. Learning and Instruction, 31, pp. 2-12.

Rivkin, S. G., Hanushek, E. A., and Kain, J. F. (2005). Teachers, schools, and academic achievement. Econometrica, 73(2), pp. 417-458.

Rockoff, J. E. (2004). The impact of individual teachers on student achievement: Evidence from panel data. American Economic Review, 94(2), pp. 247-252.

Rosch, E. (1978). Principles of categorization. In E. Rosch and B. Lloyd (Eds.), Cognition and Categorization. Hillsdale, NJ: Lawrence Erlbaum.

Rothstein, J. (2009). Teacher Quality in Educational Production: Tracking, decay, and student achievement. Princeton, NJ: Princeton University.

Rowan, B., Correnti, R., and Miller, R. (2002). What large-scale survey research tells us about teacher effects on student achievement: Insights from the prospects study of elementary schools. The Teachers College Record, 104(8), pp. 1525-1567.

Sahlberg, P. (2011). Finnish lessons: What can the world learn from educational change in Finland. New York: Teachers College Press.

Sanders, W. L., and Rivers, J. C. (1996). Cumulative and Residual Effects of Teachers on Future Student Academic Achievement. Knoxville, TN: University of Tennessee Value-Added Research and Assessment Center. Available at: http://www. mccsc.edu/ curriculum/cumulative\%20and\%20 residual\%20effects\%20of\%20teachers.pdf [Accessed 1 February 2016].

Seidel, T. and Prenzel, M. (2006). Stability of teaching patterns in physics instruction: Findings from a video study. Learning and Instruction, 16(3), pp. 228-240.

Simola, H. (2005). The Finnish miracle of PISA: Historical and sociological remarks on teaching and teacher education. Comparative Education, 41 (4), pp. 455-470.

Singh, R. and Sarkar, S. (2015). Does teaching quality matter? Students learning outcome related to teaching quality in public and private primary schools in India. International Journal of Educational Development, 41, pp. 153-163.

Smith, T.W. and Strahan, D. (2004). Toward a Prototype of Expertise in Teaching A Descriptive Case Study. Journal of Teacher Education, 55(4), pp. 357-371.

Sternberg, R.J. and Horvath, J.A. (1995). A prototype view of expert teaching. Educational Researcher, 24(6), pp. 9-17.

Stigler, J. W., Gonzales, P., Kwanaka, T., Knoll, S., and Serrano, A. (1999). The TIMSS Videotape Classroom Study: Methods and findings from an exploratory research project on eighth-grade mathematics instruction in Germany, Japan, and the United States. A Research and Development Report. Washington, DC: U.S. Department of Education, National Center for Education Statistics.

Swartz, R.J., Fischer, S.D. and Parks, S. (1998). Infusing the Teaching of Critical and Creative Thinking into Secondary Science: A lesson design handbook. California: Critical Thinking Books \& Software.

Teddlie, C., Creemers, B., Kyriakides, L., Muijs, D., and Yu, F. (2006). The International System for Teacher Observation and Feedback: Evolution of an international study of teacher effectiveness constructs. Educational Research and Evaluation, 12(6), pp. 561-582. 
A Methodological Approach for Researching National Classroom Practices

UNESCO (2014). Teaching and Learning: achieving quality for all. EFA Global Monitoring Report 2013/14. Paris: UNESCO.

Wright, S. P., Horn, S. P., and Sanders, W. L. (1997). Teacher and classroom context effects on student achievement: Implications for teacher evaluation. Journal of Personnel Evaluation in Education, 11(1), pp. 57-67. 
